\title{
Philippa Cullen: Dancing the Music
}

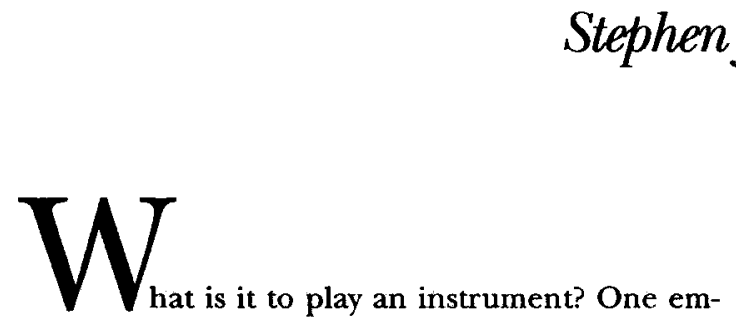

braces and touches it with the intimacy of a lover and in this touch produces sounds that could only be a product of this combination. But with electronics (certainly the electronics of David Tudor's period) there appears to be a remoteness: one twists a knob or switches a connection, but one cannot see that the action directly affects a string or a sounding membrane or a column of air. Yet this remoteness is an illusion; in actuality one's actions are mediated through those knobs or switches (a keyboard being a collection of switches), and one is (in the live situation) as much in an embrace with the instrument as with any acoustic device.

The action of making sounds is always, in some sense, a matter of being inside a system, be it a system of strings and sounding boards or a system of electronics leading to a speaker-box. One cannot stand outside the instrument, disconnected from it, and still "play" it. Involvement, being inside the process, is the basis of playing music. The gestures required in playing any instrument are movements as much as are the motions and gestures of dance.

So what is occurring in the performance situation when someone whom we would not normally consider an instrumentalist makes sounds and music from electronic instruments? This question perhaps first arose only in 1965 with John Cage's Variations $V$. In this production Billy Klüver designed a system of sensors (using radio antennas and photoelectric cells to trigger electronic sound processors); David Tudor and Gordon Mumma were the instrumentalists (their instruments being tape recorders, radios and record players); the motions of Merce Cunningham's dancers triggered the electronic processing of the sounds. Here the dancers were a major part of the process of controlling the sound and should be considered instrumentalists in this instance, as much in an embrace with the instrument as Tudor and Mumma, because they were the ones inside the operational space of antennas and lightbeams defined by Klüver's electronics. Klüver's antennas and photo-cells did not produce sounds in themselves; they merely selected the sounds that Tudor and Mumma were drawing from their instruments, a matter of switching and automated patching under the control of the dancer's motions [1].

This article describes the work of a dancer who took the idea of being inside the production of the music one step further, so that the dancer's embrace within the electromagnetic space of the system directly caused the sounds. Philippa Cullen, in the short space of her lifetime (born in Melbourne, Australia, 1950; died, 1975), took these same instrumental concepts (the

Stephen Jones (artist, electronic engineer), 387 Riley Street, Surry Hills, NSW, 2010 Australia. E-mail: <sjones@culture.com.au>

Frontispiece. Philippa Cullen and an unknown dancer working the pressure-sensitive floors at Computers and Electronics in the Arts, Canberra, 1975. (Photo $\odot$ Peter West) theremin and the photoelectric cell) and added others (pressuresensitive floors and biofeedback sensors) in her search for a means by which dancers might make their own music. Cullen researched these electronic devices, their capabilities and variations, and choreographed interactive dance works in which the performers produced the sound through detection by and direct interaction with them.

From the age of 8 years, Cullen studied primitive and jazz dance along with Jacqui Carroll, who later became a major supporter of her experimental choreography. She also studied fine arts and medieval

Fig. 1. Philippa Cullen and Manuel Nobleza checking out the Bonnet aerial, 1972. (Photo (C) Lithian Krictall) Cullen is standing on one of the Pedestal aerials. Note VCS3 in the background. Alex Ozolihs

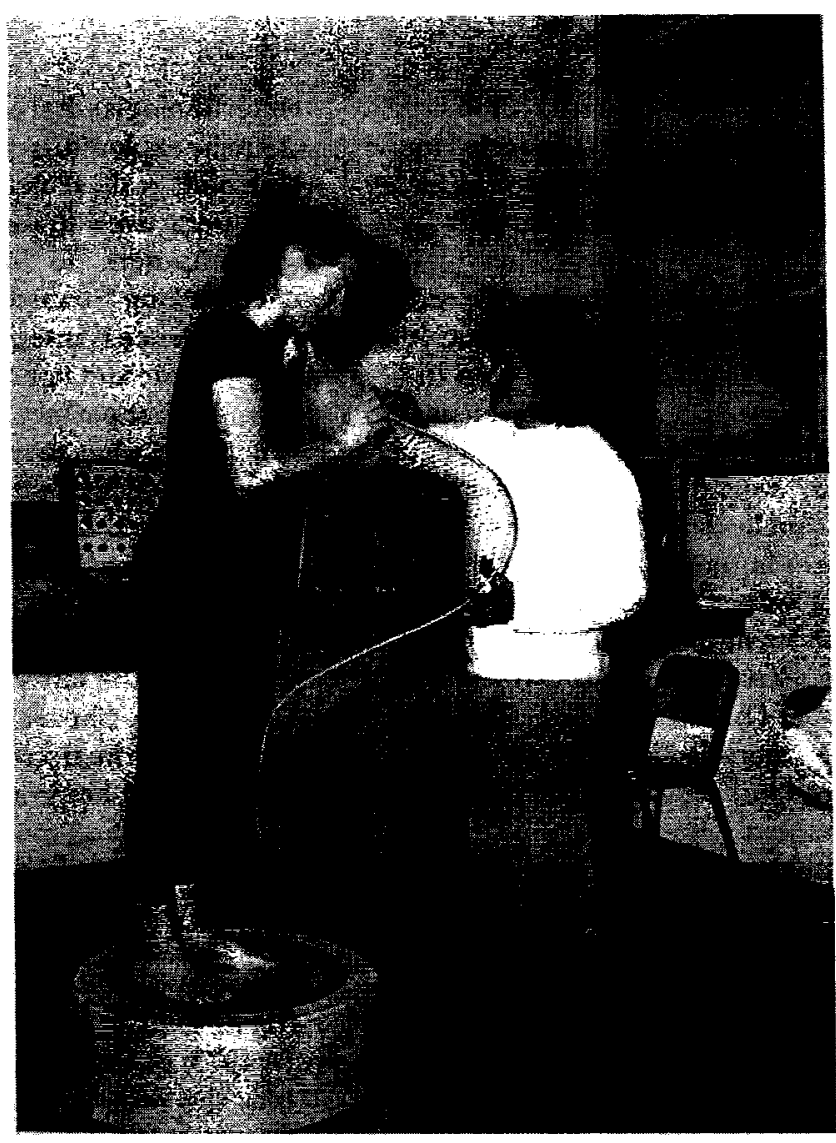



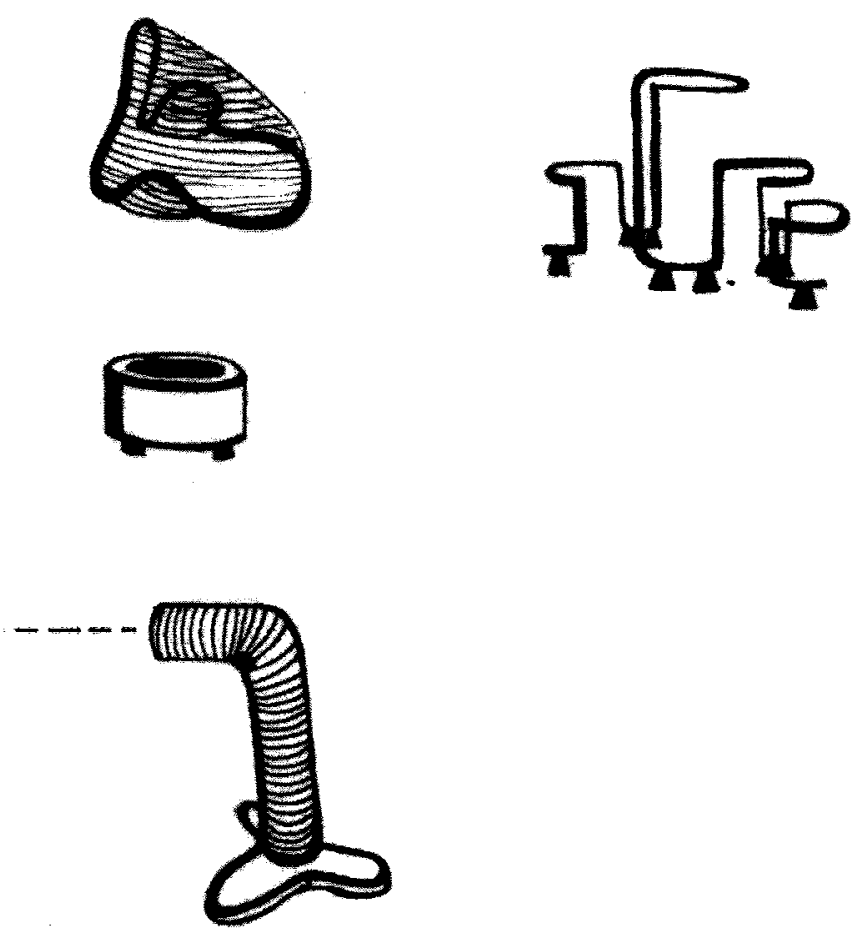

Fig. 2. A drawing of the different types of aerials $(A, B, C, \& D)$ and the photoelectric cell stand (E) that Nobleza developed for Homage to Theremin II, 1972. (Drawing $(\mathcal{1}$ Manuel Nobleza)

history at Sydney University [2]. By 1969, she had become deeply interested in the communal function of dance as exemplified in the medieval mummers (traveling actors who presented their plays in the towns of Europe) and found in African and other traditional societies. She strove to bring this function to life for the many performance artists and dancers who attended her regular Sunday workshops in the University Quadrangle and in her performance adventures in the streets and public transport of Sydney. She also became involved with those musicians who were active in experimental music in Sydney at the time. As Carroll has said, Cullen was mainly interested in the process of dance, the process of experiment [3]. Her interests tended towards the unbounded (a classic case of not knowing what one cannot do), and when she got onto some new idea she would follow it as hard as she could. She explored several approaches to this in experiments that engaged both performance and, increasingly, technical disciplines. She became entranced by the technical. Any presence of a body and thus be used to produce sounds.

Now there has been discovered a number of electronic devices which can transform human movement into dif ferent forms of energy. The detection is through radar, light intensity or a change in the electro-magnetic field around the dancer. The energy released can be converted into sound. Thus, the dancer can make his own music. But whether this discovery is taken up by the dance world depends on our readiness for this reversal of the elements and whether dancers are skilled enough to make music and whether they should be producing recognisable musical structures. The separating of dance and music in the Merce Cunningham group and the work in silence of some other companies seems to me a good preparation for this new relation. It releases the dancer from the imposed dynamics and time of the music and forces a new independence. I have for the last three years worked with these new electronic media which I have developed into body instruments. Just as the use of new material of prefabricated concrete changed the shape of the building and the life of the people inside, so I found that the use of electronics changed my concept of dance and my values for dancers [6].

\section{ELECTRONIC ASPECTS}

It is not clear when she first thought about the potential for an electronically mediated interaction in producing sound for dance, but around mid-1969, Cullen saw an interactive environment that Optronic Kinetics (David Smith, Jim McDonnell and Kaz Kondziolka), a group of electronic engineers and artists who were interested in interactivity and luminal kinetics, had built at the Fine Arts Workshop at Sydney University [7]. The installation was set in a room with a grid of black-and-white tiles spread over the walls lit with ultraviolet light and consisted of a theremin with a long wire as the aerial strung around the walls "so that the audience could create sound and light patterns" [8]. In addition to producing the usual sine-wave sounds, the outputs of the theremin's two oscillators were hooked up to the deflection coils of a TV set, making it respond like an oscilloscope in producing Lissajous figure images, which were given color with the aid of a rotating color filter wheel synchronized to the frequency of the theremin's primary oscillator [9].

Cullen was evidently quite inspired by the installation and mentioned it in a notebook from the period. "David Smith, electrical engineer, constructed an 'objet d'art' for the Fine Arts work- 
shop which reacts by light \& noise to any interference. He wants to compose músic for bállet" [10].

This is Cullen's first known experience with an interactive device. As she later noted:

This was just what I had been waiting for-a device which switched the relation of movement and sound; now the dancer could create music. Of course it was two and a half years before anything resembling dance was producing anything resembling music [11].

The installation appears to have been the fundamental trigger to Cullen's achieving her interest in undoing the tight dependency of dance upon music [12]. She asked the Optronic Kinetics group to build a theremin for her, which was realized after some experimentation. It used "a triangle of copper wire [that] produced an electro-magnetic field that covered the whole stage ${ }^{n}$ [13] With this theremin, dancers could produce the sounds directly from their vn movement. In May 1970 Cullen choreographed the ballet Electronic Aspects for it,

with the dancers judging their distance from it and producing a changing sine tone which corresponded exactly with their position in relation to the aerial. ... A theremin detects the capacitance of the body, i.e. the electrical potential. . . . Each aerial has an electric field around it which you disturb with your body. The disturbance is proportional to the mass, not to speed. [But] things are limited with one theremin and only wire for an aerial [14].

Electronic Aspects was choreographed for nine dancers - three main dancers (Alain Israel, Jacqui Carroll and Brian Coughran) and six who formed a "cho rus." Cullen's choreographic notes indicate the kind of movement that she elieved would produce interesting, conarolled sounds through the theremin:

Find mov[emen]t[s] of small width which will produce a small variation in sound at various levels with various parts of the body. Experiment with each. Then make full use of whole range.

Arms-hands

Rise

Body breathing. . . . Back horizontalrocking

Arms hands moving

Hands to release. ... roll onto one knee

Stand. Drama of hands [15]

The stage setting consisted of the triangle of wires forming the aerial for the theremin. The dancers "surged up and down the wires" [16], affecting the frequency of the sounds from the theremin. All the audience heard were the sine- wave sounds of the theremin. Cullen was not satisfied with the sound the theremin itself made-she thought it was very crude [17], which led to her attempts to broaden the ways in which it might produce sounds. Yet the ballet was an important step in bringing the dancer inside the music, where the dancer becomes the instrumentalist, even if on an inadequately diverse instrument. Several experimental steps then developed.

One was her 1971 ballet, Utter, which she choreographed for the Ballet Australia Choreographic Competition. Based on phonemes from the four languages that George Alexander spoke, Utter "explored the use of the voice as a sound source for dance" and received a special mention in the competition [18]. Cullen presented Utter again in April 1972 for AZ Music's Sound Ventures III. As

Fig. 3. Philippa Cullen rehearsing with the wire loop aerials in the Music Department, Univer-

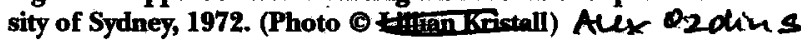

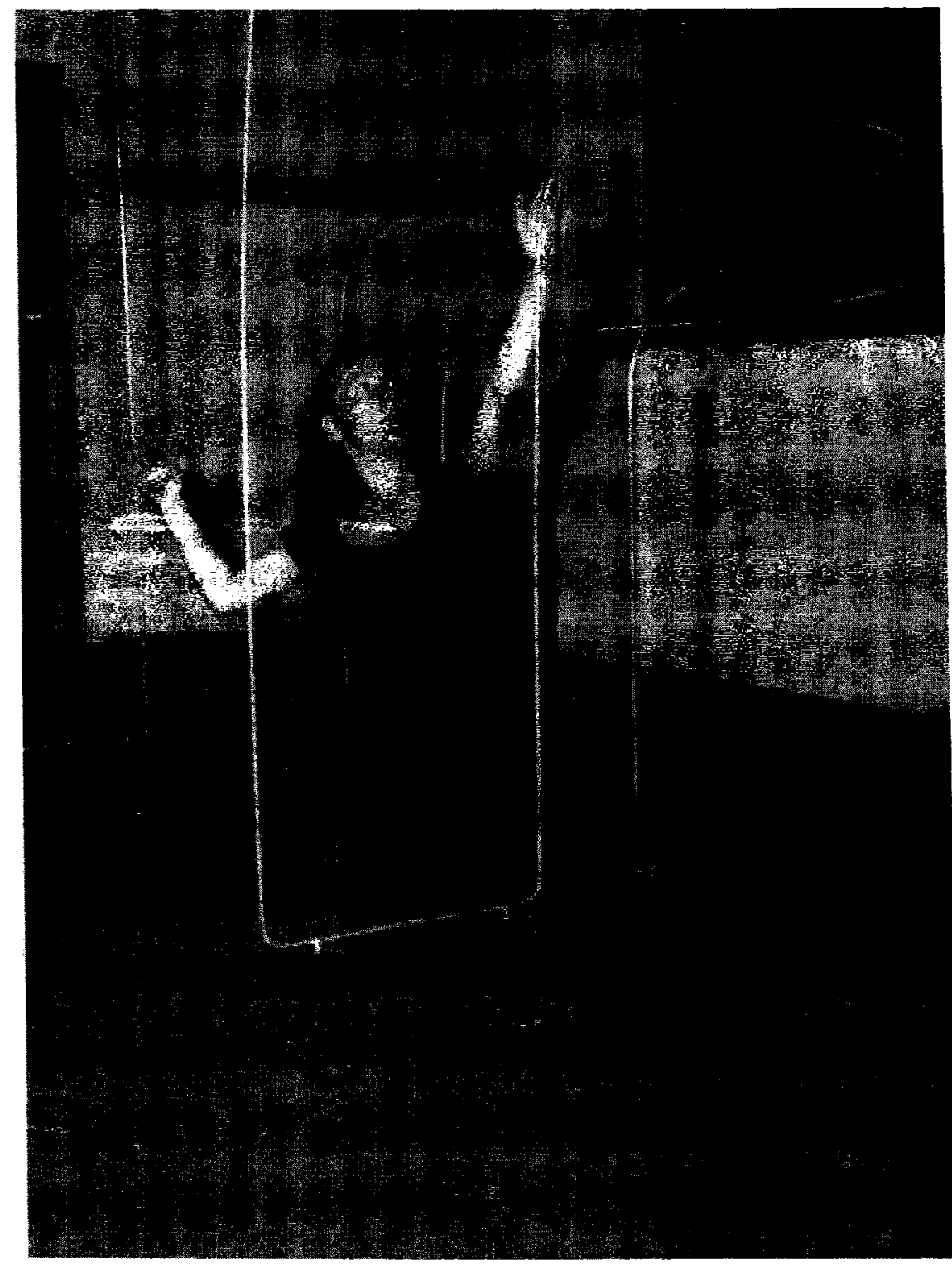

one reviewer described it, the sound came directly from the four dancers who

hissed, chanted, droned, whispered and shrieked their own stream-ofconsciousness accompaniment as they pranced around in a cleared space in the centre of the auditorium. . . . It was ... [f] ull of vitality, sometimes as beautiful as a temple frieze, sometimes deliberately ugly, occasionally just for fun [19]

Another was in her work with improvisational musicians whose performance trajectory could follow the movements of the dancer. Cullen had been attending experimental music workshops run by Sydney composer David Ahern since 1969 [20]. From these workshops he had established a group of avant-garde musicians known as AZ Music to perform works by John Cage, Cornelius Cardew, Ia Monte Young and others who more 


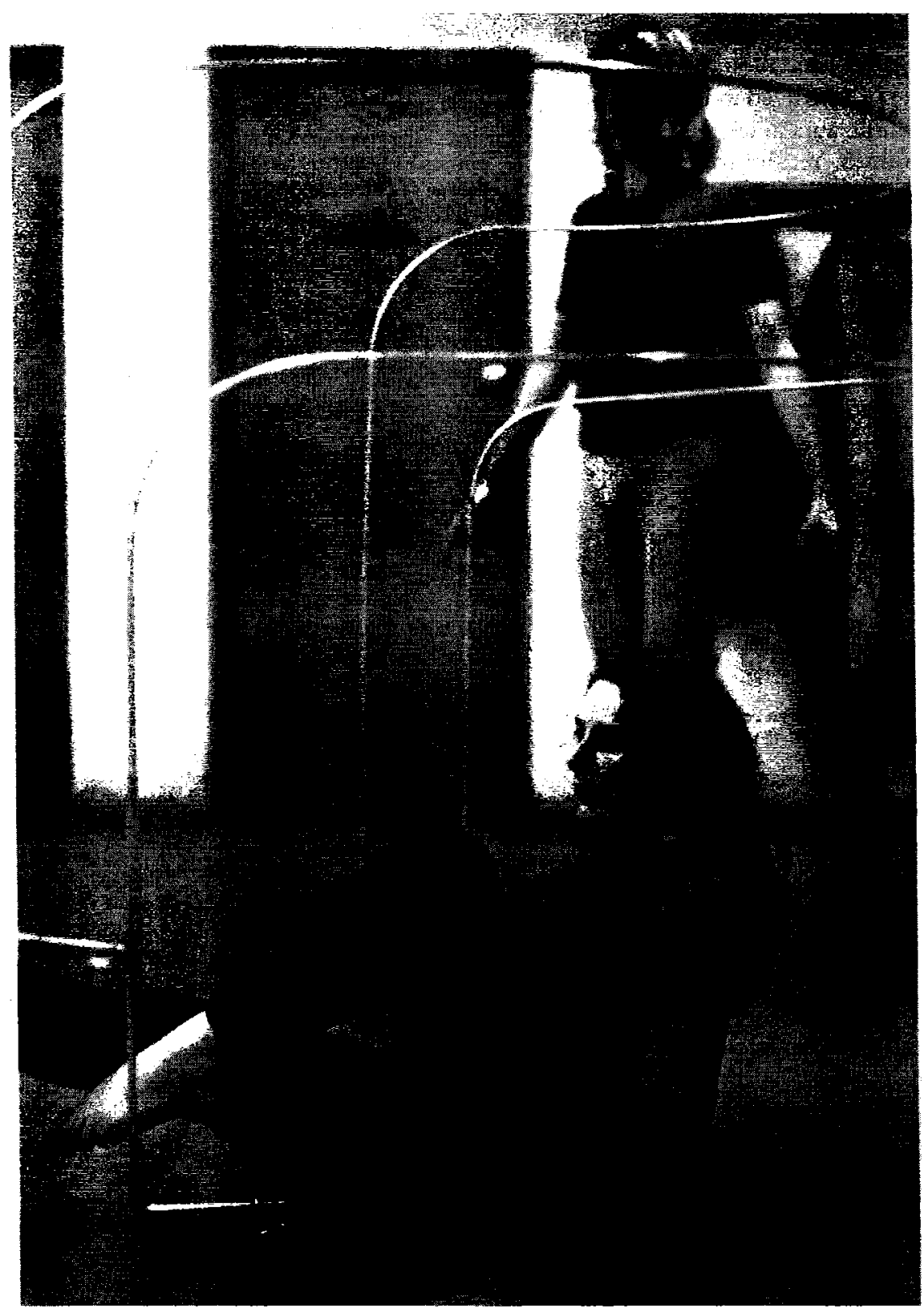

Fig. 4. Philippa Cullen and Peter Dickson rehearsing with the wire loop aerials in the Music Department, 1972. (Photo 을 Lillian Kristall)

often used graphical scores (or lists of instructions) than actual notated music. Cullen danced in the AZ Music productions of Cage's Imaginary Landscape No. 4 (in 1970) and Cardew's Great Learning (February 1971) [21]. During AZ Music's Sound Ventures series, she danced with the electroacoustic improvisation group Teletopa [22], in Sound Ventures II, at Inhibodress Gallery (13 April 1972). According to the reviews, this was the highlight of the night. David Gyger wrote in The Australian newspaper: "There seemed to be incredible rapport between the electronic improvisations of Teletopa and the evocative dancing of Philippa Cullen" [23].

Maria Prerauer, in her review of the evening, also in The Australian, wrote: the performance (represented in its extreme in $4^{\prime} 33^{\prime \prime}$, where the whole performance is incidental sound, bracketed only by the opening and closing of the keyboard lid), nor Tudor's approach in Rainforest, where the listeners wander among the sound sources distributed through the auditorium, each being "inside the music," since the whole improvisational production is driven from inside its production process. Here the dancer is working to the music as the music is following the dancer, producing a single performance emergent, greater and more fascinating than either alone.

\section{HOMAGE TO THEREMIN II}

In the year and a half between Electronic Aspects and the Sound Ventures series, while teaching dance and working with AZ Music, Cullen "went looking for technicians and composers to assist her in developing [the theremin's] musical capacity" [25]. The electronic aspect of her work then became of primary interest. She asked Greg Schiemer, a music composition student at the university, to help her with the theremin. He initially rejected the idea because the theremin, by itself, can manipulate only the pitch of the sound. However, he was interested in the way it was operated and wanted to be able to do more with its sound, so he suggested hooking it up to a synthesizer. $\mathrm{He}$ felt that "it would be good if you could alter some of the other parameters of the sound, not just the pitch but the intensity and the harmonic structure and a few other things" [26]. At about the same time, Cullen met another electrical engineer, Phil Connor, who had already been experimenting with the theremin. He had also built a frequency-to-voltage converter to allow the theremin to control a voltage-controlled synthesizer, and this combination offered a solution for producing more complex and interesting sounds from the theremin's output, especially as it might be controlled by a dancer's movements.

In early 1972 Cullen received a grant from the Australian Council for the Arts to pursue the development of her electronic interactions and established Philippa's Electronic Dance Ensemble with Connor, Schiemer and a number of other dancers and engineers interested in electronic music and computing [27]. They entered an intense period of development work over the first 3 months of 1972. The ensemble's objectives were "to discover and employ many of the various relationships between sound and movement which occur when using elec- 
tronic instruments such as the theremin" [28], in order to realize the potential for the dancer to produce music through the use of body-sensing devices and other forms of interactive technology.

Donald Peart, head of the Music Department at Sydney University, and Brian Campbell, who had installed the electronic music studio there, gave Cullen access to two EMS VCS3 audio synthesizers. Connor designed new theremins and a set of frequency-to-voltage converters to connect them to the synthesizers [29]. Two theremins were used for each VCS3: one to control pitch and the second to control other parameters. Greg, as composer, worked out how to produce interesting sounds from this system. Manuel Nobleza, an architecture student, designed a range of possible large-scale aerials that Cullen tried out (Fig. 1). Among these were the triangle of wires that she had used in the 1970 ballet Electronic Aspects; an S-shaped upright surface that was stable but restricted the dancer's range; and various vertical and horizontal loops of wire, some of which produced complex electric fields that made it difficult for the dancer to get consistent results. David Moore accidentally discovered the pedestal aerial when he stood on a plate aerial lying on the floor [30]. The final set adopted for performance work can be seen in Nobleza's drawing (Fig. 2).

The music department had also provided rehearsal space for the 3 months leading up to the performance, and although it was very difficult for dancers to learn to deal with the vagaries of four interacting theremin aerials in the space and to constrain their movements so as to get interesting and controlled sounds from the synthesizers, a major ballet was developed (see Figs. 3-4). This production from the ensemble was the performance of Homage to Theremin II, held in the auditorium of International House at Sydney University (26 July 1972). Dancers included Jacqui Carroll, Peter Dickson and Maggie Knightly (see Figs. 5-6). Beth Dean reviewed the performance for the Sydney Morning Herald:

As we listened to the pre-set sound of the banshee wail, a roaring of the sea, a bit of a squeak, any of which could occur when a movement interrupted the flow of a light beam on a photo-electric cell, or whenever a person approached or receded from any of the four cleverly shaped aerials, we wondered when the spirit of the dance could escape the fetters of the rules of the machine! [31]

Dean goes on to describe a moment in the performance:

Jacqui Carroll took her place upon a circular pedestal base (aerial A). This cre- ated a quiet humming tone. As she slowly extended her arm upwards the pitch (frequency) [of the] sound rose louder and higher.

The mood developed to an intensity of yearning. The fingers opened. She reached out stretching both the sound and the body to taut heights of thinnest strain. She clenched her fist. The tone of audible sound and visual tension receded [32].

The next week Cullen and her company gave a demonstration of the theremin technology at the New South Wales Conservatorium of Music (see Fig. 7). In her report to the Australian Council for the Arts, Cullen commented that there had not been enough time

given to the development of skills for the dancer and musician to play the theremin. Also I think the VCS3's should or could be more versatile if attached to a well-programmed computer system specifically designed to control the sequence of aerial and patch-board (VCS) changes [33]

\section{EUROPE}

Following Homage to Theremin II, Cullen received a grant from the Australian Council for the Arts to travel to Europe to further her studies of the use of electronics in dance. She had expected the European dance scene would have been more advanced than Australia, but she failed to find anyone "who had any knowledge of dance with electronics" [34].

Cullen arrived in Paris in August and then went to London to attend the In-

Fig. 5. Jacqui Carroll and Philippa Cullen dancing with the wire loop aerials in rehearsal for Homage to Thenemin $I$ at International House, Sydney University, 1972. (Photo @ Lillian Kristall) In the background are Phil Connor (right) and Greg Schiemer (left) at the VCS3 consoles. Standing against the back wall are Nobleza and a colleague.

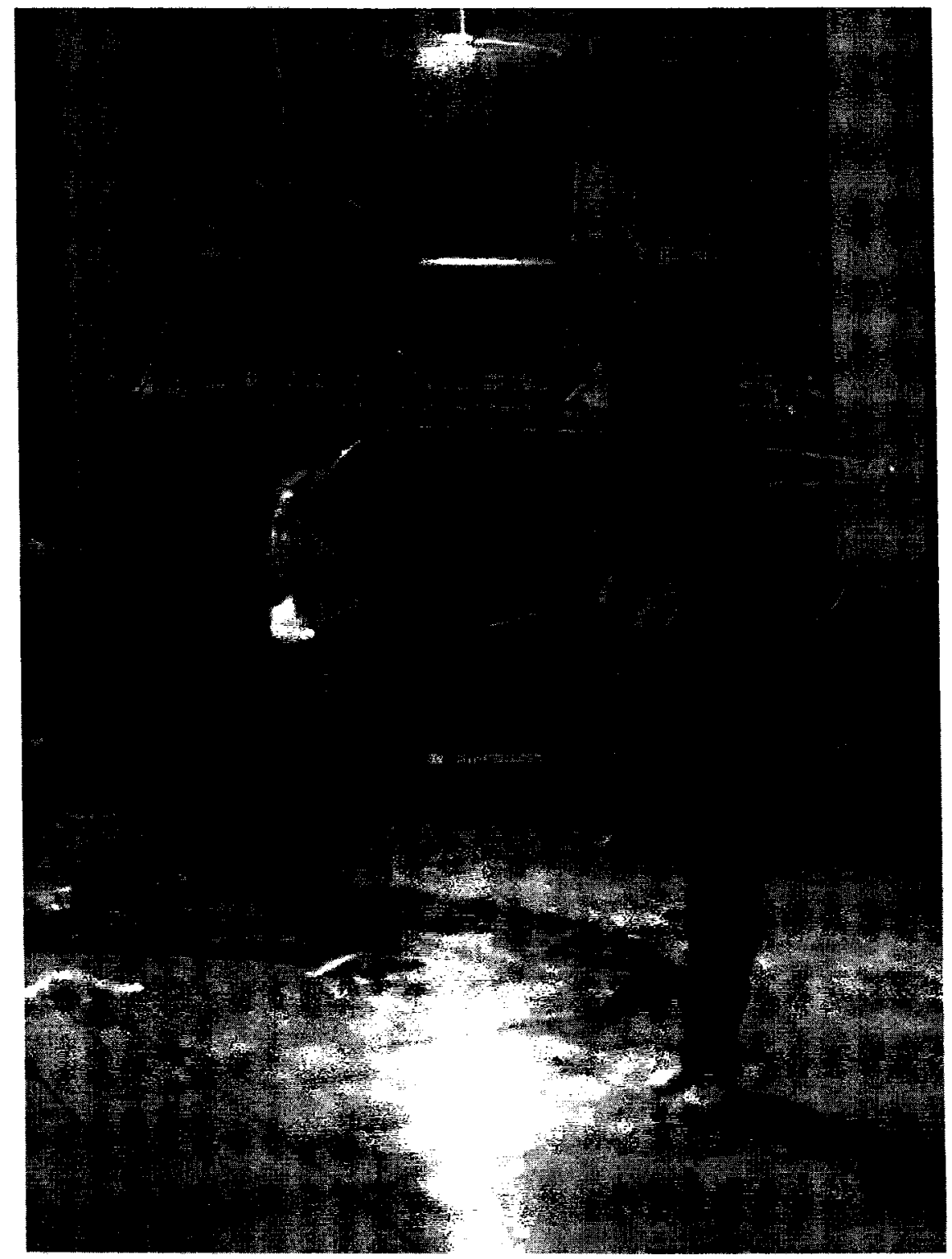


ternational Carnival of Electronic Sound (ICES 72) [35]. She showed some video documentation of her work and met Mumma and Tudor, who, she notes: "expressed enthusiasm to work with the theremins in exactly the same way as we did in 1972" [36]. She also performed with Teletopa and with Cornelius Cardew's Scratch Orchestra. From London, she traveled to Munich to perform with the Scratch Orchestra at the 1972 Olympic Games Spielstrasse (the arts festival of the Munich Olympics). After Munich she went to Essen to study with Pina Bausch at the Folkwang Hochschule for a month and then, in October, went on to the Institute of Sonology in Utrecht, where she studied electronics, mathematics and computer composition.
While studying, she developed a proj-ect for a performance series using pressure-sensitive floors and a pair of theremins that were built for her by students [37]. She had a great deal of trouble getting the electronic instruments finished, largely because having no real financial support meant she had to rely on volunteer help. Although only some of the pieces of equipment she wanted were built, these did include the theremins, built for her by a student (Derek Schut) from Delft University, and the pressure-sensitive floors for which the Studio for Electro-Instrumental Music (STEIM) in Amsterdam produced the electronics. Charles Simons, an engineer at the Institute of Sonology, suggested that she experiment with detecting the

Fig. 6. Philippa Cullen and Jacqui Carroll on the pedestal aerials in performance of Homage to Theremin II at International House, 1972. (Photo @ Lillian Kristall)

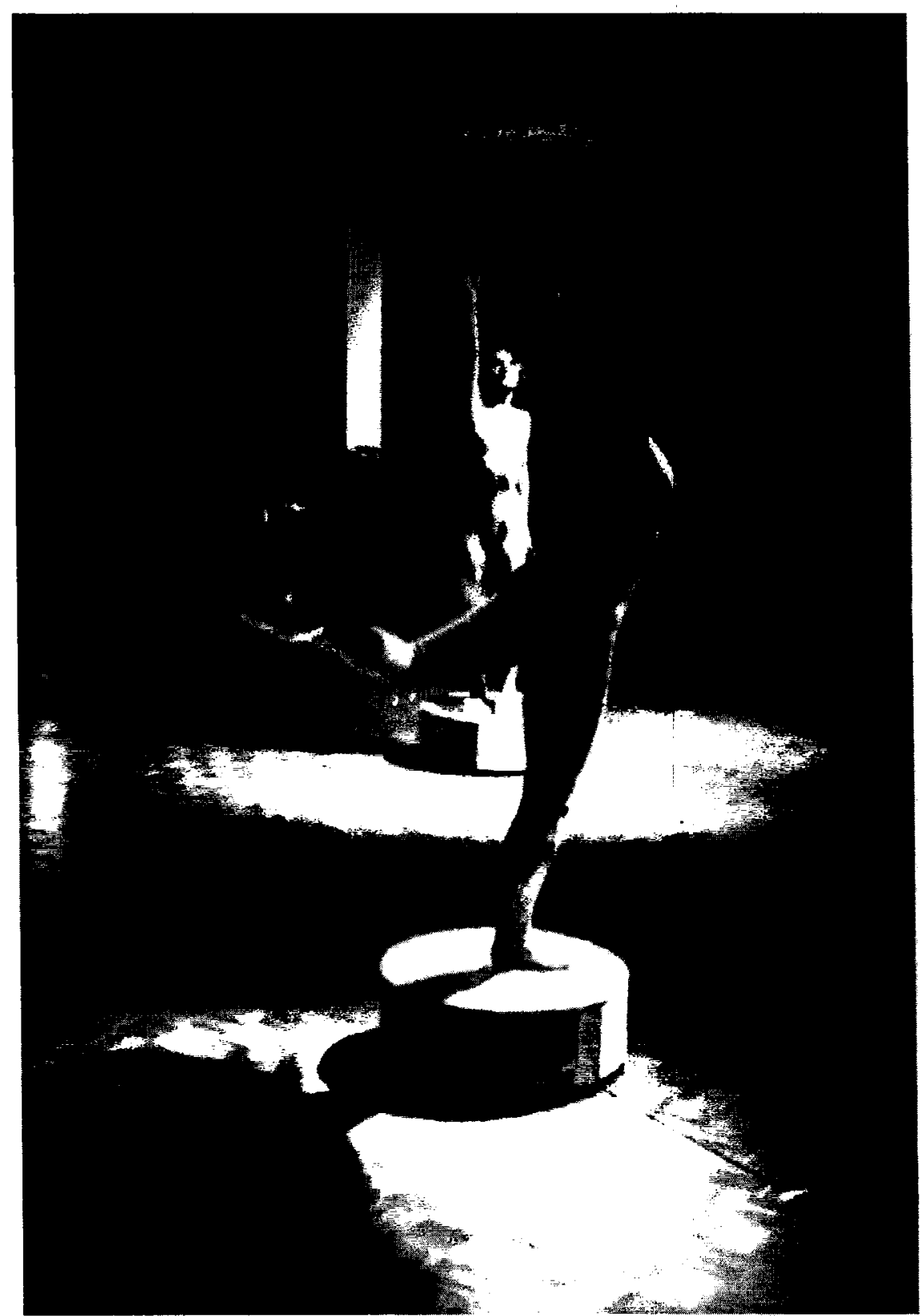

positions of the dancers by using photoelectric cells attached to a video screen * displaying a high-contrast camera image of the performance area [38]. William York at STEIM helped her with the synthesizers for rehearsals and performances. Cullen herself had to become the technical coordinator. She commented, "This had advantages in that I myself learned a lot about synchronisation of equipment and connection requirements. But a willing person for this job is essential" [39].

She and the dancers she had gathered presented a series of talks and performances of her ideas in Amsterdam (27 April 1973), Rotterdam (25 May) and Eindhoven ( 1 and 3 June).

After Utrecht, Cullen went to work with Stockhausen in Germany. She had met Stockhausen in Hobart during his tour to Australia in 1970 [40] when she was helping out with the equipment. She spent time with him at his home in Germany and is credited with inspiring his use of the gestures of prayer (particularly the Hindu mudra, which she had been studying as part of her choreographic work), in his composition Inori (19731974). She also danced with a theremin controlling a synthesizer during the Summer Night Music concerts held by Stockhausen's students and associates, the Ōldorf Group, at a farmhouse in Öldorf near Kurten in Germany [41].

In her report to the Australian Council for the Arts (31 May 1973), she stated that she would come home to continue her research in Australia because it was "a place to develop new things and ideas," with many people who were willing and talented and who possessed the necessary enthusiasm [42]. She left Europe in August 1973. On her way home she spent 3 months in Ghana, where she explored the role of dance in the African community, and several months in India at Sri Aurobindo's ashram Auroville, presenting workshops and learning Indian dance technique.

Cullen arrived back in Australia in mid-1974 and began working again with composer Schiemer and dancer Carroll. She presented a series of seminars over 9 days at One Central Street gallery in Sydney (1-11 July 1974), giving workshops and demonstrations of what she had learned on her travels, including her various electronic and biofeedback instruments [43]. The seminars at One Central Street brought a wide group of people together, and she demonstrated much of the equipment that she had been using and talked about the role of dance in the New Music culture of Eu- 


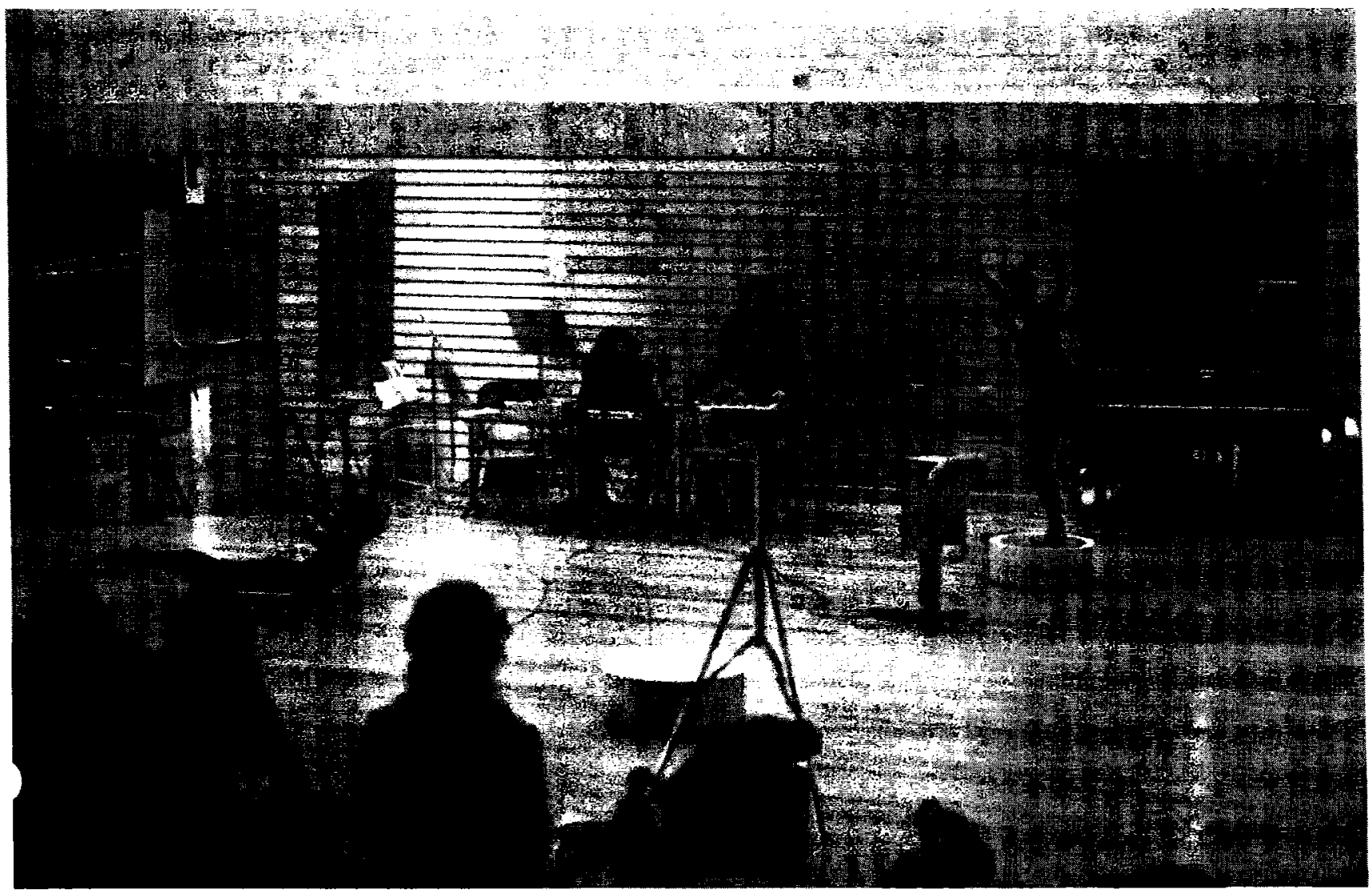

Fig. 7. Demonstrating the theremins to music students at the NSW Conservatorium of Music, Sydney, 1972. (Photo 9 Iillian Kristall). Shown are Philippa Cullen on the floor, Maggie Knightly on the pedestal aerial, Phil Connor and an unidentified colleague at the instruments, and Nobleza standing against the wall.

rope and Australia and its communal role in the cultures of Africa and South Asia. She talked about her experience with new dance in Holland and electronic music by Stockhausen, as well as the work at the Institute of Sonology and at Öldorf. She gave dance workshops and performances with Carroll and other dancers and musical experiments, including theremin works, with Schiemer and Connor, among others.

She also produced demonstrations of the possibilities of biofeedback instruments in dance with the aid of Ariel of Bush Video. While in Europe, Cullen had read M.L. Eaton's Bio-Music [44], and in a talk to the Rotterdam Dance Academy she commented:

\begin{abstract}
Already in bio-music the human body becomes all important. Blood circulation, rate of breathing, muscle tension, eye movements, even brain waves can be detected electronically and fed back to the person so that he can learn to control these things in a previously unheard of way [45].
\end{abstract}

Recognizing that biofeedback could be used as a source of sound and control voltages, she decided that she wanted to work with various biosensors, including an electromyogram (muscle electrical ac- tivity detector) and a breath detector. She had only been able to get access to the electromyogram at the Anatomy Lab in the University of Utrecht, but had not been permitted to use it for performances. Through the electromyogram experiments, she realized that although body signals could be detected there remained the problem of

what to do with the signal produced. I do not like any feedback system which artificially manipulates any organic function; there is no real correspondence between these aspects of movement and the parameters of sound, i.e., not that I can find though I am still working on it [46].

The equipment was also difficult to access in Australia, however, and her experiments did not go very far.

\section{COMPUTERS AND ELECTRONICS IN THE ARTS}

In 1975 Cullen was invited to perform at the Computers and Electronics in the Arts exhibition organized by Doug Richardson for Australia 75 (7-16 March 1975) [47]. She was also invited to give a series of workshops and performances at the 6 th Mildura Sculpture Triennial. She used her fees from the exhibition and the performances [48] to buy an EMS Synthi A (a variant of the VCS3), which she intended to use with a new set of pressure-sensitive floors built for her by Arthur Spring. These four triangular floors were hinged on one edge, with a pressure sensor (made up of a light bulb, an aperture and a light-dependent resistor) on the opposite apex. As the dancers moved over them, the floors sent out voltages that reflected the position of the dancer on the floor, enabling the dancers to use the floors to control the sounds created.

Cullen brought the floors and the synthesizer to the exhibition and set up there with Bush Video and the many others involved. Unfortunately (or perhaps, fortunately, as the story develops) the connection between the floors and the synthesizer failed, and Cullen found that she and her dancers (Helen Herbertson, Brian Coughran and Wayne Nichols) were not going to be able to make music this way. The problem did not seem fixable, so Cullen decided that they should go home, but this brought a number of the people who had systems in the ballroom together to solve the problem for her. Iain MacLeod and Chris Ellyard (of Australian National University Engineer- 


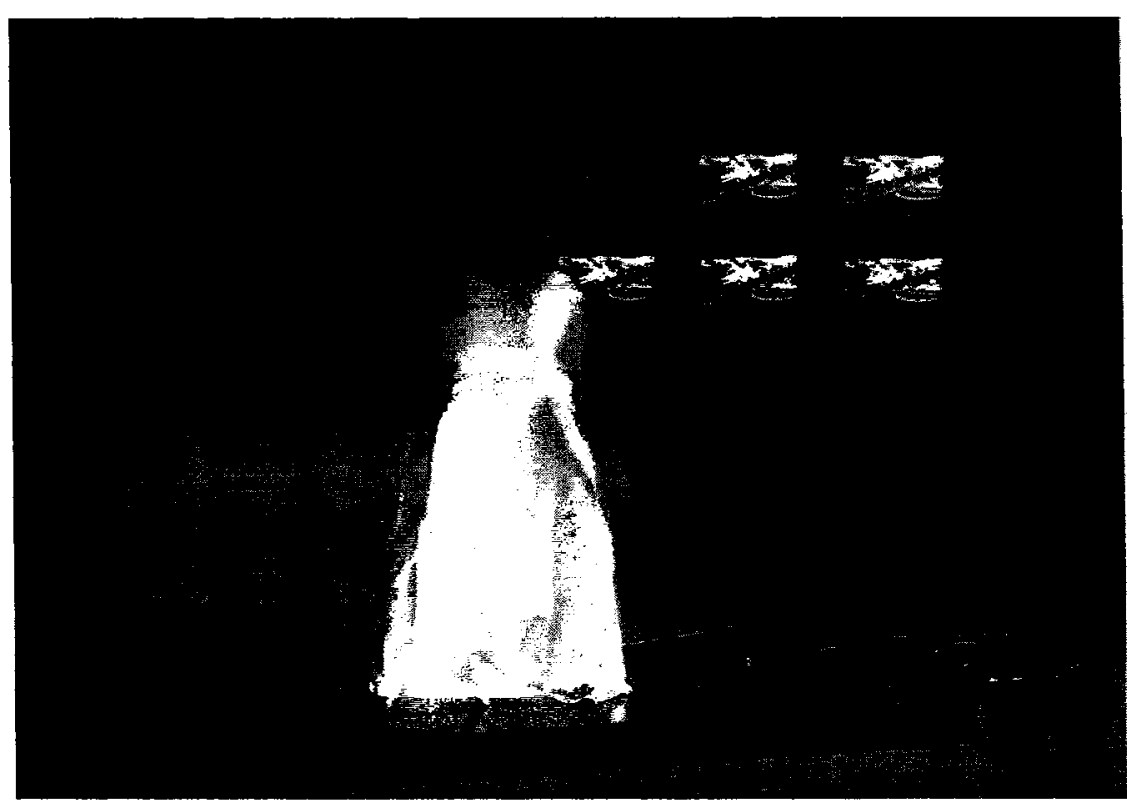

Fig. 8. Philippa Cullen working the pressure-sensitive floors during a performance at Computers and Electronics in the Arts at Australia 75, Canberra, March 1975. (Photo 0 Peter West.) Note the floor traces displayed on the wall of monitors on the stage.

ing Physics) were running a PDP-11/40 computer lent by Digital Equipment Corporation. They had an analog-to-digital converter on the PDP-11 and had also built a 512-pixel- $X-512$-line- $X-4$-bits-perpixel image-buffer with ferrite-core memory for it Overnight they wrote the driver software that would allow the computer to read the floors, using this data to draw a "history" of the dancer's movements as an image. The image was then sent to John Hansen's video synthesizer, where it was combined with camera images of the dancers and video feedback. The output was displayed on a bank of color video monitors. "One floor controlled horizontal position of a moving spot, a second controlled vertical position, a third altered the spot size and the fourth floor selected the spot colour" [49]. The image was faded selectively so that it was replaced slowly over an interval of about a minute. The dancers now were no longer inside the music, but perhaps more radically were directly controlling the construction of video images (see Fig. 8 and Frontispiece). As the computer now had the signal from the floors for the video, the dancers worked to music supplied by Steve Dunstan and his hand-built audio synthesizers, which also supplied audio modulation for keying (matte) control of Hansen's video synth.

[The dancers] spent many hours learning how to use this new medium before they could concentrate once again on interpreting the music they were dancing to rather than on producing the desired image. We found that simple and direct relationships between the movements on the floors and the behaviour of the moving spot were required. Thus, leaning to the right on one floor moved the spot to the right while leaning forward on another floor caused the spot to move down [50].

Performances on this integrated system drew large crowds, and opportunities to play with the system were taken up at every possible instance. All this happened almost overnight and illustrates just how much interest there was in integrating all sorts of disparate systems, as well as how willing everyone was to do everything possible to make this integration work.

At the Mildura Sculpture Triennial (April 1975) Cullen presented a series of workshops involving people from the community, both as participants and as observers in dance systems intended to break up their normal perceptions of what dance was about. She gave several performances, including a theremin event and a theremin workshop. In her report on the performances in Mildura she remarked on the experiences of audiences and dancers.

The instruments themselves are however very accessible to members of the public, even children, because anybody can move. The hard part is to programme the synthesiser so that you are controlling a variable which is satisfying for the operator of the floors. And this is precisely the part of the system which is completely unknown to all but the initiated few. But I shall go on exploring the field because I am interested in the thresholds of perception [51].

But she never got to pursue this: To everyone's horror, Cullen died in India in
July 1975, and experimental art in Australia lost one of its inspirations. Neiver theless, in the few years that she had worked, Cullen took the original experiment of Cage, Klüver, Cunningham, Mumma and Tudor and brought the Australian dance, music and art worlds face to face with interactivity by placing herself and her dancers deeply inside the music.

\section{References and Notes}

1. Michael Nyman, Experimental Music, Cage and Beyond (London: Studio Vista, 1974).

2. Cullen graduated in 1970 with a Bachelor of Arts. Jilba Wallace, "Philippa Cullen: A Life's Work," Writings on Dance 4 (Spring 1989) p. 9.

3. Jacqui Carroll, in Jilba Wallace, Philippa Cullen: A Life's Work (videotape, 1976).

4. Philippa Cullen, "Application to the Australian Council for the Arts for assistance in 1971/1972" (1971), the Cullen Archive, College of Fine Arts (COFA) Library, Sydney.

5. George Alexander, conversation with the author, 3 February 2003.

6. Philippa Cullen, Towards a Philosophy of Dance," privately published (June 1973); republished in Writings on Dance 4 (1989) pp. 19-25.

7. A theremin circuit by Leo Simpson was published in Electronics Australia (June 1969).

8. Philippa Cullen, "Electronic Projects, 1970," in "Project 1973 Holland," report to the Australian Council for the Arts, dated 31 May 1973, the Cullen Archive, COFA Library.

9. A theremin consisis of two high-frequency oscillators that beat (or heterodyne) together. The primary oscillator is set at a fixed frequency, while the secondary oscillator has an external aerial that is sensitive to the stray capacitance in its immediate environment for its frequency-setting capacitor. If anyone comes near it, the aerial picks up their body capacitance, thus altering the frequency of the secondary oscillator, so that when the outputs of the two oscillators are summed they produce a beat frequency in the auditory range. The theremin thus produces sine waves of a frequency determined by the distance of the stray body capacitance from its aerials. Although most theremins come with two aerials, only one (used to produce the frequency) is necessary. The second is generally used to control the volume of the oscillators' beat output.

10. Philippa Cullen, manuscript notebook including her choreographic notes for Electronic Aspects, 1969. The Cullen Archive, COFA Library.

11. Philippa Cullen, "Lecture/Demonstration Delivered to Rotterdam Dance Academy, "November 1972. The Cullen Archive, COFA Library.

12. Alexander [5]

13. Cullen [8].

14. Cullen [11].

15. Cullen [10].

16. Carroll, in Wallace [3].

17. Cullen [10].

18. Jacqui Carroll, "Philippa Cullen" (obituary), Sydney (September 1975), in Art Almanac (SeptemberDecember 1975) (Ewing Gallery, Melbourne). In the University of Adelaide Archives, series 200.

19. Maria Prerauer, "Probing into New Dimensions," review of AZ Music's Sound Ventures series performance by the group Teletopa, which included a per- 
formance of Utter, in The Australian (23 April 1972) p. 22

20. GeoffreyBarnard, conversation with the author, Bondi Junction, 21 November 2003.

21. Geoffrey Barnard, "AZ It Was," New Music Articles 7 (1989); < http://www.rainerlinz.net/NMA/repr/ Barnard.html>.

22. The name derives from the Greek, roughly: the distant source of ideas; see Barnard [20].

23. David Gyger, "Silhouettes on the Very Edge of Musical Experience," review of AZ Music's Sound Ventures $I \mathcal{E}^{\circ}$ II in The Australian (18 April 1972) p. 10.

24. See Prerauer [19].

25. See Wallace [2] p. 11.

26. Greg Schiemer in Wallace [3].

27. The other engineers included Brian Campbell, Jim McDonnell, Doug Richardson and David Moore; David Smith was then living in France (and working for Frank Malina). Besides Cullen, the dancers included Jacqui Carroll and Maggie Knightly and Peter Dickson.

\section{Cullen [4]}

29. Greg Schiemer, "Greg Schiemer," biographical note in John Jenkins, ed., 22 Contemporary Australian Composers (Melbourne: NMA Publications, 1988). Also available at <http://www.rainerlinz.net/ NMA/22CAC/schiemer.html>

30. Philippa Cullen, "Philippa's Electronic Dance Ensemble, "report to the Australian Council for the Arts (1972), the Cullen Archive, COFA Library. Note: The pedestal aerial theremin very much resembles Theremin's Terpsitone, although it is unlikely that anyone in Cullen's ensemble would have known of it

31. Beth Dean, "Experiments in the Sound of Body Movement, " Sydney Morning Herald (28 July 1972) p. 20: review of Philippa's Dance Ensemble presentaion of Homage to Theremin II at International House, 26 july 1972.

32. Dean [31]. The (aerial A) refers to the Pedestal aerial in Fig. 1.

33. Cullen in Schiemer [29].

34. Cullen [8]

35. Philippa Cullen, draft copy of the Report to the Australian Council for the Arts (1973), the Cullen Archive, COFA Library.

36. Cullen [8], cover letter.

37. Cullen [8].

38. A variation of this idea reappears some years later in the development of 3DIS and its use by Warren Burt. See Warren Burt, "The SDIS System," Sounds Australian 19 (1988) pp. 27-33.

39. Cullen [8].

40. Michael Kurtz, Stockhausen: A Biography, Richard Toop, trans. (London: Faber \& Faber, 1992) p. 196.

41. Kurtz [40] p. 200.

42. Cullen [8].

43. Philippa Cullen, "A Programme for Dance," catalogue, programme of the seminars, One Central
Street, Sydney, 1-11 July 1974, the Cullen Archive, COFA Library.

44. Manford L. Eaton, Bio-Music (Barton, VT: Something Else Press, 1974).

45. Cullen [11].

46. Cullen [8].

47. See Stephen Jones, "Synthetics: A History of the Electronically Generated Image in Australia, Leonardo 36, No. 3, 187-195 (2003).

48. See letters to Tom McCullough and Stephan Haag, the Cullen Archive, COFA Library.

49. I.D.G. MacLeod and C.J. Ellyard, "The Computer Arts-Reflections on 'Australia 75," Proceedings of the Digital Equipment Computer Users Society (Digital Equipment Computer Users Society) Melbourne, Australia, August 1975.

50. See MacLeod and Ellyard [49].

51. Philippa Cullen, "Activities and Impressions," in her report to the Australian Council for the Arts on the "City for Sculpture," the 6th Mildura Sculpture Triennial (1975), the Cullen Archive, COFA Library.

Manuscript received 30 December 2003.

Stephen Jones is an Australian video and in stallation artist and electronic engineer. He de veloped the Brain Project web site <http:// wrwwculture.com.au/brain_proj/ $>$. He is cur rently writing a history of the electronic arts in Australia. 